\title{
Effect of different placement techniques on color stability and surface roughness of resin composites
}

\author{
Efeito das técnicas de inserção e alisamento na estabilidade de cor e \\ rugosidade superficial de resinas compostas
}

\section{Fernanda KERPEL ${ }^{a}$ (D) , Ana Carolina BAMBERG ${ }^{b}$ (D), Gabriel Ferreira NICOLOSOc ${ }^{(D)}$,

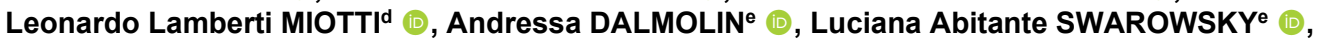 Marcela MARQUEZAN ${ }^{\mathrm{e}}$ (D), Letícia Brandão DURAND ${ }^{\mathrm{e}^{*}}$ (1)}

${ }^{a}$ Cirurgiã-dentista, Prefeitura de Indaial, Secretaria da Saúde, Fundo Municipal da Saúde de Indaial, Indaial, SC, Brasil ${ }^{\text {b} C i r u r g i a ̃-d e n t i s t a, ~ G r a d u a d a ~ p e l a ~ U n i v e r s i d a d e ~ F e d e r a l ~ d e ~ S a n t a ~ M a r i a, ~ P o ́ s-g r a d u a d a ~ p e l a ~ U n i v e r s i d a d e ~ F e d e r a l ~ d o ~}$ Rio Grande so Sul, Três de Maio, RS, Brasil

'Faculdade Inedi - Cesuca, Cachoeirinha, RS, Brasil

dUFRGS - Universidade Federal do Rio Grande do Sul, Porto Alegre, RS, Brasil

eUFSM - Universidade Federal de Santa Maria, Santa Maria, RS, Brasil

How to cite: Kerpel F, Bamberg AC, Nicoloso GF, Miotti LL, Dalmolin A, Swarowsky LA, et al. Effect of different placement techniques on color stability and surface roughness of resin composites. Rev Odontol UNESP. 2021;50:e20210004.

https://doi.org/10.1590/1807-2577.00421

\section{Resumo}

Introdução: A longevidade e o sucesso clínico das restaurações dentárias podem ser influenciados por muitos fatores durante os procedimentos restauradores. Objetivo: Avaliar a influência da técnica de alisamento na estabilidade de cor e rugosidade superficial de duas resinas compostas. Material e método: Os grupos de amostras ( $\mathrm{n}=10$ ) foram divididos conforme a resina composta (Filtek ${ }^{\mathrm{TM}} \mathrm{Z} 250$ XT e Filtek ${ }^{\mathrm{TM}}$ Z350 XT) e as técnicas empregadas: tira de poliéster, espátula, pincel seco, selante de superfície. A cor e a rugosidade da superfície foram avaliadas por espectrofotômetro (espaço de cor CIELab) e rugosímetro (corte padrão de 0,8 mm), respectivamente, após o armazenamento em água. Posteriormente, as amostras foram imersas em café por $48 \mathrm{~h}$ e a cor final foi aferida. Os dados foram analisados usando teste ANOVA e Tukey post hoc $(\alpha=5 \%)$ e a correlação entre rugosidade da superfície ( $\left.\mathrm{R}_{\mathrm{a}}\right)$ e variação de cor $\left(\Delta \mathrm{E}_{\mathrm{ab}}\right)$ através do coeficiente de correlação de Pearson. Resultado: As técnicas de alisamento influenciaram a $\mathrm{R}_{\mathrm{a}}$ e a $\Delta \mathrm{E}_{\mathrm{ab}}$ em ambas as resinas compostas. Os grupos tratados com selante de superfície apresentaram maior diferença na $\Delta \mathrm{E}_{\mathrm{ab}}$. A resina Filtek ${ }^{\mathrm{TM}} \mathrm{Z} 250 \mathrm{XT}$ apresentou maior estabilidade de cor comparada à Filtek ${ }^{\mathrm{TM}}$ Z350 XT, independentemente da técnica utilizada. A $\mathrm{R}_{\mathrm{a}}$ das técnicas de alisamento foi semelhante entre os compósitos, exceto para o grupo do líquido modelador da Filtek ${ }^{\mathrm{TM}} \mathrm{Z350}$ XT, que apresentou os menores valores. Uma correlação entre $\mathrm{R}_{\mathrm{a}}$ e manchamento $(p=0,268)$ foi identificada. Conclusão: A estabilidade da cor e a $\mathrm{R}_{\mathrm{a}}$ são influenciadas pelas técnicas de alisamento utilizadas.

Descritores: Materiais dentários; estética dental; coloração.

\begin{abstract}
Introduction: Longevity and clinical success of dental restorations can be influenced by many factors during the restorative procedures. Objective: This study aimed to evaluate the influence of different placement techniques on color stability and surface roughness of two resin composites. Material and method: The groups of specimens $(\mathrm{n}=10)$ were divided according to resin composite (Filtek ${ }^{\mathrm{TM}} \mathrm{Z} 250 \mathrm{XT}$ and Filtek $^{\mathrm{TM}}$ Z350 XT) and placement technique: Mylar strip, spatula, dry brush, modeling liquid, and surface sealant. Color stability and surface roughness were accessed using a spectrophotometer (CIELab color space) and a rugosimeter (standard cutoff of $0.8 \mathrm{~mm}$ ), respectively, after water storage. Subsequently, the specimens were immersed in coffee for $48 \mathrm{~h}$ and final color was measured. The data were analyzed using ANOVA and the Tukey's post hoc test $(\alpha=5 \%)$ and the correlation between surface roughness $\left(\mathrm{R}_{\mathrm{a}}\right)$ and color change $\left(\Delta \mathrm{E}_{\mathrm{ab}}\right)$ was assessed using the Pearson's correlation coefficient. Result: The different placement techniques influenced $\mathrm{R}_{\mathrm{a}}$ and $\Delta \mathrm{E}_{\mathrm{ab}}$ on both resin composites. The groups treated with surface sealant showed greater difference in $\Delta \mathrm{E}_{\mathrm{ab}}$ for both resin composites. The Filtek ${ }^{\mathrm{TM}} \mathrm{Z} 250 \mathrm{XT}$ resin showed greater color stability compared with the Filtek ${ }^{\mathrm{TM}} \mathrm{Z350}$ XT resin regardless of the placement technique used. $\mathrm{R}_{\mathrm{a}}$ of
\end{abstract}


each placement technique was similar among the resin composites except for the Filtek ${ }^{\mathrm{TM}} \mathrm{Z350}$ XT modeling liquid group, which presented lower $\mathrm{R}_{\mathrm{a}}$ values compared with those of Filtek ${ }^{\mathrm{TM}} \mathrm{Z} 250$ XT. A correlation between $\mathrm{R}_{\mathrm{a}}$ and staining was identified $(p=0.268)$. Conclusion: Color stability and $\mathrm{R}_{\mathrm{a}}$ are influenced by different placement techniques.

Descriptors: Dental materials; dental esthetic; staining.

\section{INTRODUCTION}

Resin composites are frequently applied in esthetic dental restorations ${ }^{1}$. The use of these composites through well-executed techniques provides restorations with excellent clinical performance over time and, due to their positive mechanical and optical properties, they are presented as a conservative solution for many cases².

Resin composite composition and properties play an important role in the longevity and esthetics of restorations ${ }^{3}$. In general, these materials are basically composed of an organic matrix, inorganic filler particles, a silane coupling agent, and curing initiators ${ }^{4,5}$. The size and arrangement of filler particles are directly related to the surface roughness $\left(R_{a}\right)$ of resin composites. Rough surfaces may increase the susceptibility of staining by deposition of pigments, favor plaque accumulation and, consequently, the development of gingival inflammation and secondary caries ${ }^{6,7}$.

The introduction of nanoparticles represents an evolution of these materials. Increased filler content provides smoother surfaces as a result of the smaller size and better distribution of the fillers in the resin matrix ${ }^{8}$. The characteristics of the monomers present in the organic matrix are also important to the clinical performance of resin composites. Hydrophobic monomers are associated with greater color stability compared with hydrophilic monomers, which tend to stain in higher proportions due to water affinity 8 .

Longevity and clinical success of restorations may be influenced by factors related to operator experience as well as to the manipulation, insertion and smoothing techniques used during the restorative procedures ${ }^{10,11}$. The placement protocol used in clinical practice is partially applied empirically, and knowledge of its effects regarding the quality and longevity of restorations is still unclear ${ }^{12}$.

There are many placement and smoothing techniques for direct resin composite restorations. The most commonly used are spatulas, Mylar strips, brushes, modeling liquids, and application of surface sealants to protect the restoration ${ }^{12-14}$. Although these techniques are widely applied, few studies have evaluated their effects on resin composite restorations. Most studies only compare different polishing procedures and evaluate the influence of surface sealants application on the $\mathrm{R}_{\mathrm{a}}$ and color stability of materials ${ }^{15-17}$. Therefore, the influence of placement, manipulation and smoothing techniques on the quality and longevity of restorative procedures is still unclear, remaining an empirical issue.

In this context, this study aimed to evaluate the influence of placement techniques on the color stability and $R_{a}$ of two resin composites. The null hypothesis tested was that the different placement techniques would not influence the $\mathrm{R}_{\mathrm{a}}$ and color stability of the resin composites used.

\section{MATERIAL AND METHOD}

\section{Study Design}

This in vitro study evaluated the color stability and surface roughness $\left(\mathrm{R}_{\mathrm{a}}\right)$ of the Filtek ${ }^{\mathrm{TM}} \mathrm{Z} 250$ XT and Filtek ${ }^{\mathrm{TM}}$ Z350 XT (3M ESPE St. Paul, MN, USA) resin composites using different placement 
techniques: Mylar strip, spatula, dry brush, modeling liquid, and surface sealant application. Figure 1 presents the flowchart of study design and group division. The shade, composition, manufacturer, and batch number of the materials are described in Table 1.

\section{Group Division and Specimen Preparation}

The groups were divided according to resin composite and placement technique. A stainless steel matrix measuring $8.0 \mathrm{~mm}$ in diameter and $2.0 \mathrm{~mm}$ in thickness was used to prepare the discshaped specimens $(n=10)$ by a trained and calibrated operator. The placement techniques used for each group preparation are described below:

\section{Group 1 - Mylar strip}

The resin composite was applied by placing an increment into the matrix using a spatula and covering it with a Mylar strip. In order to obtain a flat and uniform surface, a $2 \mathrm{~mm}$-thick glass plate was placed over the Mylar strip. After that, the resin composite was light cured for $20 \mathrm{~s}$ on each side using a light-emitting diode (LED) (Bluephase, Ivoclar Vivadent, Schaan, Liechtenstein) with $1000 \mathrm{~mW} / \mathrm{cm}^{2}$ irradiance. After removal of the glass plate, the specimens were light cured for another $20 \mathrm{~s}$ and stored in distilled water at $37^{\circ} \mathrm{C}$ for $24 \mathrm{~h}$.

\section{Group 2 - Spatula}

An increment of the resin composite was applied into the matrix and a flat and uniform surface was obtained using of a spatula (Suprafilln 1, SSWhite). Then the resin composite was light activated on both sides for $20 \mathrm{~s}$ as previously described. In order to ensure the complete polymerization of the surface layer, a glycerin gel was applied and additionally light cured for another $20 \mathrm{~s}$. After that, the specimens were stored as previously described.

\section{Group 3 - Dry Brush}

The resin composite was placed as described for Group 2 and then a dry brush was used to obtain a smooth surface. The brush was gently applied on the surface twice in each direction according to the following sequence: from left to right; from right to left; from top to bottom; from bottom to top. After that, each specimen was light cured and stored as previously described.

\section{Group 4 - Modeling liquid}

This group followed the same sequence of the previous groups; however, instead of using only the dry brush, the resin composite was smoothed using a brush with a drop of adhesive (Adper Single Bond 2 - 3M ESPE, St. Paul, MN, USA), which was used as modeling liquid, and then light cured and stored as previously described.

\section{Group 5 - Surface sealant}

This group was prepared as in Group 2 and immersed in water for $24 \mathrm{~h}$. Then the specimens were polished and the surface sealant was applied as follows: all specimens were gently dried with absorbent paper and etched with a 37\% phosphoric acid for $30 \mathrm{~s}$, rinsed for $60 \mathrm{~s}$, and dried with a stream of compressed air. A drop of surface sealant (Natural Glaze, DFL, Jacarepaguá, RJ, 
Brazil) was gently applied using a brush according to manufacturer's instructions on the top surface of the specimen and light cured for $20 \mathrm{~s}$. A glycerin gel layer was applied on the surface sealant and light cured for additional $20 \mathrm{~s}$ to prevent inhibition of the oxygen layer.

\section{Storage and Polishing}

After light activation, the specimens were stored in distilled water at $37^{\circ} \mathrm{C}$ for $24 \mathrm{~h}$ prior to polishing. All groups of specimens, expect the Mylar strip group, were polished under dry conditions using medium, fine and extra-fine abrasive discs (Soft - Lex Pop On, 3M ESPE, St. Paul, MN, USA). Each disc was used for $20 \mathrm{~s}$ with a hand piece $(10,000 \mathrm{rpm})$ and discarded after use on six specimens. To remove debris after each stage, the specimens were rinsed with running water for $10 \mathrm{~s}$ and air dried for $5 \mathrm{~s}$. After completion of the polishing stage and for the baseline condition prior to testing, the specimens were immersed again in water for $24 \mathrm{~h}$ as previously described and then had their color stability and $\mathrm{R}_{\mathrm{a}}$ measured.

\section{Staining}

For color stability evaluation, all groups of specimens were immersed in coffee solution $(3.6 \mathrm{~g}$ of coffee powder dissolved in $300 \mathrm{ml}$ of boiling water according to manufacturer's instructions) at $37 \stackrel{\circ}{-} \mathrm{C}$ for $48 \mathrm{~h}^{18}$.

\section{Color Stability}

Color stability was accessed before (baseline) and after coffee staining using a reflection spectrophotometer (SP60 - EX-Rite/Grand Rapid, MI, USA) in triplicate according to the CIE $\mathrm{L}^{*} \mathrm{a}^{*} \mathrm{~b}^{*}$ color space ${ }^{19}$ (Commission Internationale de I'Eclairage). This color system is a tridimensional color measurement: $\mathrm{L}^{*}$ refers to the lightness coordinate and its value ranges from 0 for perfect black to 100 for perfect white, $a^{*}$ and $b^{*}$ are chromaticity coordinates on the greenred $\left(-a^{*}=\right.$ green; $+a^{*}=$ red $)$ and blue-yellow $\left(-b^{*}=\right.$ blue; $+b^{*}=$ yellow $)$ axes.

Each specimen was positioned on a white background and evaluated under the same environmental conditions. Before color measurements, the spectrophotometer was calibrated according to the manufacturer's instructions. After staining, all specimens were rinsed with running water and dried with absorbent paper for final color measurement.

Color change was calculated according to CIELAB formula: $\Delta \mathrm{E}_{\mathrm{ab}}=\left(\left(\Delta \mathrm{L}^{*}\right)^{2}+\left(\Delta \mathrm{a}^{*}\right)^{2}+\left(\Delta \mathrm{b}^{*}\right)^{2}\right)^{1 / 2}$.

\section{Surface Roughness}

Surface roughness $\left(R_{a}\right)$ was assessed using a rugosimeter (Suftest SJ - 201P, Mitutoyo, Tokyo, Japan) with a diamond tip of $5 \mu \mathrm{m}$ in diameter, angled $90^{\circ}$ at $0.5 \mathrm{~mm} / \mathrm{s}$. A total of six measurements $\left(\mathrm{R}_{\mathrm{a}}, \mu \mathrm{m}\right)$ per specimen were performed: three in the $x$-axis and three in the $y$-axis. The cut-off used was $0.8 \mathrm{~mm}$ of $4 \mathrm{~mm}$ length. The $\mathrm{R}_{a}$ parameter was calculated by the average of the measures performed in the center of each specimen.

\section{Statistical Analyses}

Normal distribuition of the data was verified by the Shapiro-Wilk test. The mean $\Delta \mathrm{E}$ and $\mathrm{Ra}$ values were analyzed by Two-way ANOVA and the Tukey's test ( $\alpha=5 \%)$. The Student's $t$-test was 
applied to compare $\mathrm{R}_{\mathrm{a}}$ and color stability between the resin composites (nanohybrid and nanofilled) $(p<0.05)$ Correlation between $\mathrm{R}_{\mathrm{a}}$ and $\Delta \mathrm{E}_{\mathrm{ab}}$ was verified using the Pearson's correlation coefficient. All data analyses were performed using the Statistical Package for Social Sciences Software (SPSS 20.0; SPSS, Chicago, IL, USA).

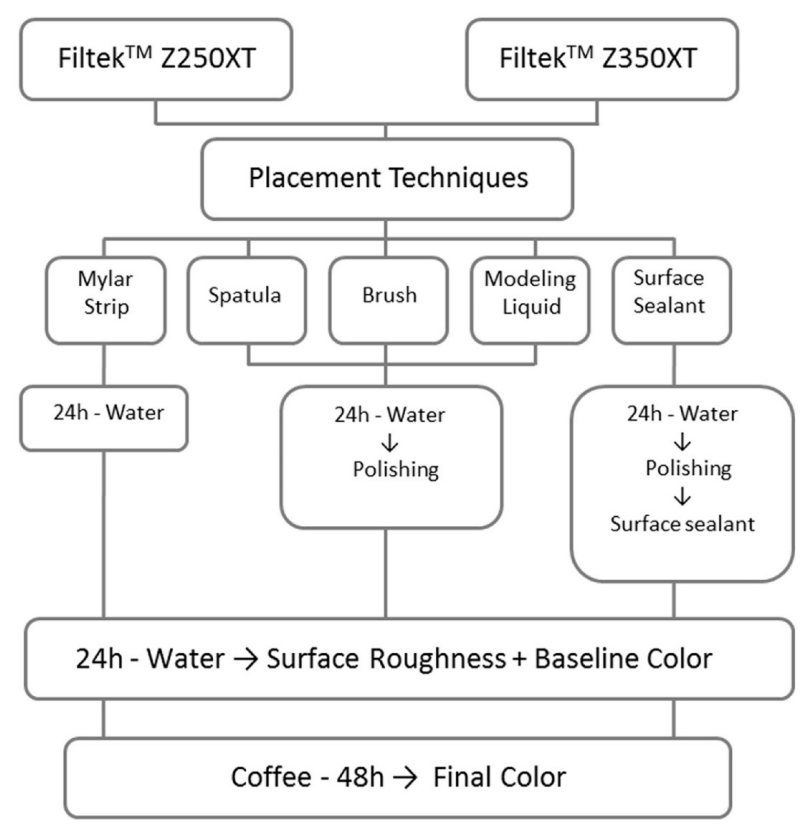

Figure 1. Flowchart of study design and group division.

Table 1. Shade, composition, manufacturer, and batch number of the materials used in this study

\begin{tabular}{|c|c|c|c|c|}
\hline Material & Shade & Composition & Manufacturer & Batch Number \\
\hline $\begin{array}{c}\text { Filtek }^{\mathrm{TM}} \mathrm{Z250XT} \\
\text { (Nanohybrid) }\end{array}$ & A2 & $\begin{array}{c}0.01 \mu \mathrm{m} \text { to } 3.50 \mu \mathrm{m} \text { Bis-GMA, } \\
\text { UDMA BisEMA }\end{array}$ & $\begin{array}{c}\text { 3M ESPE (St. Paul, } \\
\text { Minnesota, USA) }\end{array}$ & 37277 \\
\hline $\begin{array}{l}\text { Filtek }^{\mathrm{TM}} \mathrm{Z350XT} \\
\text { (Nanofilled) }\end{array}$ & A2E & $\begin{array}{c}0.004 \mu \mathrm{m} \text { to } 0.02 \mu \mathrm{m} \text { Bis-GMA, } \\
\text { UDMA BisEMA }\end{array}$ & $\begin{array}{c}\text { 3M ESPE (St. Paul, } \\
\text { Minnesota, USA) }\end{array}$ & 17664 \\
\hline $\begin{array}{c}\text { Natural Glaze } \\
\text { (Surface Sealant) }\end{array}$ & - & $\begin{array}{l}\text { Bis-GMA, TEGDMA, 2,6-tert- } \\
\text { butylphenol, ethylurethane, } \\
\text { B200P, BenzylDimethylKetal, } \\
\text { Camphorquinone, Quantacure } \\
\text { EHA }\end{array}$ & $\begin{array}{c}\text { DFL (Jacarépagua, } \\
\text { RJ, Brazil) }\end{array}$ & 12112053 \\
\hline $\begin{array}{l}\text { Adper Single Bond } 2 \\
\text { (Single Bottle } \\
\text { Adhesive) }\end{array}$ & - & $\begin{array}{c}\text { Bis-GMA, HEMA, } \\
\text { dimethacrylates, polyalkenoic } \\
\text { acid copolymer, } \\
\text { camphorquinone, ethanol, } \\
\text { water, dimethacrylate, } \\
\text { glycerol } 1.3,10 \text { wt } \% \text { silica } \\
\text { filler }\end{array}$ & $\begin{array}{l}\text { 3M ESPE (St. Paul, } \\
\text { Minnesota, USA) }\end{array}$ & N504822 \\
\hline
\end{tabular}

Captions: Bis-GMA: bisphenyl glycidyl dimethacrylate, UDMA: urethane dimethacrylate, BisEMA: ethoxylated bisphenol-A dimethacrylate, TEGDMA: triethylene glycol dimethacrylate.

\section{RESULT}

The color change $\left(\Delta \mathrm{E}_{\mathrm{ab}}\right)$ means and standard deviations obtained are presented in Table 2. Interaction between factors (resin composite and placement technique) was statistically significant $(p<0.05)$. Intergroup analysis revealed a statistical difference between the resin 
composites for each placement technique, with lower $\Delta \mathrm{E}_{\mathrm{ab}}$ values for Filtek ${ }^{\mathrm{TM}} \mathrm{Z} 250 \mathrm{XT}$. Statistical difference was also observed in the intragroup analysis between the placement techniques for each resin composite. The highest $\Delta \mathrm{E}_{\mathrm{ab}}$ value was observed when surface sealant was applied to both resin composites.

Surface roughness $\left(\mathrm{R}_{\mathrm{a}}\right)$ means and standard deviations are presented in Table 3. Intergroup analysis revealed the same $R_{a}$ pattern between resin composites for each placement technique, except for the Filtek ${ }^{\mathrm{TM}} \mathrm{Z350}$ XT - modeling liquid group, which presented lower $\mathrm{R}_{\mathrm{a}}$ values compared with the Filtek ${ }^{\mathrm{TM}}$ Z250 XT - modeling liquid group. Statistical difference was also observed in the intragroup analysis between the placement techniques for each resin composite. The lowest $\mathrm{R}_{\mathrm{a}}$ value was observed in the Mylar Strip group for both composites. Similar $\mathrm{R}_{\mathrm{a}}$ results were observed between the other placement techniques for Filtek ${ }^{\mathrm{TM}} \mathrm{Z} 250 \mathrm{XT}$. In contrast, the Filtek $^{\mathrm{TM}} \mathrm{Z350} \mathrm{XT}$ resin presented greater variation in the $\mathrm{R}_{\mathrm{a}}$ pattern between the different placement techniques, with the highest $\mathrm{R}_{\mathrm{a}}$ value obtained in the Spatula group.

The Pearson' correlation coefficient $(0.268)$ revealed a weak and positive correlation between color stability and $\mathrm{R}_{\mathrm{a}}$.

Table 2. Color change ( $\Delta \mathrm{E}^{*}{ }_{\mathrm{ab}}$, mean \pm standard deviation) of resin composites and placement techniques

\begin{tabular}{lccccc}
\hline $\begin{array}{c}\text { Resin } \\
\text { Composites }\end{array}$ & Mylar Strip & Spatula & Dry Brush & $\begin{array}{c}\text { Modeling } \\
\text { Liquid }\end{array}$ & Surface Sealant \\
\cline { 2 - 5 } & $5.65(1.04)^{\mathrm{Aa}}$ & $6.22(1.08)^{\mathrm{Aa}}$ & $5.89(0.66)^{\mathrm{Aa}}$ & $5.60(0.81)^{\mathrm{Aa}}$ & $9.73(0.62)^{\mathrm{Ab}}$ \\
$\begin{array}{l}\text { Filtek }^{\mathrm{TM}} \\
\begin{array}{l}\text { Z250XT } \\
\text { Filtek TM }\end{array}\end{array}$ & $7.82(0.89)^{\mathrm{Bb}}$ & $8.82(0.82)^{\mathrm{Bc}}$ & $7.19(0.69)^{\mathrm{Bab}}$ & $6.66(0.59)^{\mathrm{Ba}}$ & $10.66(0.77)^{\mathrm{Bd}}$ \\
\hline Z350XT &
\end{tabular}

Different uppercase letters in columns indicate significant difference intergroup $(p<0.05)$. Different lowercase letters in lines indicate significant difference intragroup $(p<0.05)$.

Table 3. Surface roughness ( $R_{a}$, mean \pm standard deviation) of resin composites and placement techniques

\begin{tabular}{|c|c|c|c|c|c|}
\hline \multirow{2}{*}{$\begin{array}{c}\text { Resin } \\
\text { Composites }\end{array}$} & \multicolumn{5}{|c|}{ Techniques } \\
\hline & Mylar Strip & Spatula & Dry Brush & $\begin{array}{c}\text { Modeling } \\
\text { Liquid }\end{array}$ & Surface Sealant \\
\hline $\begin{array}{l}\text { Filtek }^{\mathrm{TM}} \\
\text { Z250XT }\end{array}$ & $0.11(0.02)^{\mathrm{Aa}}$ & $0.45(0.13)^{\mathrm{Ab}}$ & $0.43(0.12)^{\mathrm{Ab}}$ & $0.45(0.09)^{\mathrm{Ab}}$ & $0.48(0.11)^{\mathrm{Ab}}$ \\
\hline $\begin{array}{l}\text { Filtek }^{\mathrm{TM}} \\
\text { Z350XT }\end{array}$ & $0.13(0.05)^{\mathrm{Aa}}$ & $0.53(0.10)^{\mathrm{Ac}}$ & $0.35(0.14)^{\mathrm{Ab}}$ & $0.34(0.12)^{\mathrm{Bb}}$ & $0.46(0.12)^{\mathrm{Abc}}$ \\
\hline
\end{tabular}

Different uppercase letters in columns indicate significant difference intergroup $(p<0.05)$. Different lowercase letters in lines indicate significant difference intragroup $(p<0.05)$.

\section{DISCUSSION}

Several placement techniques are applied during the insertion, accommodation, shaping, and contouring of resin composite restorations. Sculpting instruments, brushes, Mylar strips, modeling liquids, and application of surface sealants are widely used in clinical practice. Although these techniques are frequently used, few studies have evaluated their influence on the properties and final outcome of restorations $13,14,20$.

Color stability of resin composites is an expected feature and, ideally, the restoration color should be stable overtime ${ }^{13}$. Due to esthetic demands, color change in resin composite restorations is considered as one of the major causes of restoration replacement in the anterior area $^{1,10}$. Restorations with smooth surfaces and color stability depend on many factors, such as eating and parafunctional habits of the patient, ability and experience of the operator, and 
effectiveness of the polishing systems, as well as on properties and characteristics inherent in the resin composites and placement techniques $8,10,12,13,21$.

Extrinsic discoloration of resin composites is considered a relevant issue for restoration longevity ${ }^{12}$. Absorption and adsorption of food and beverage pigments may lead to restoration degradation ${ }^{14,22}$. The present study used immersion in coffee for staining not only because this is a widely consumed beverage, but also because the coffee pigments have small molecular weight and can easily penetrate in the resin composite 22 . According to the National Coffee Association (NCA), the average daily consumption of coffee is $3.2 \mathrm{cups}^{23}$. Assuming that the consumption time among coffee drinkers is of about 5-15 min, $48 \mathrm{~h}$ of immersion in coffee should simulate approximately two months of coffee consumption ${ }^{18}$.

For accurate color measurement, objective methods are preferable over visual ones, because results are not affected by subjective interpretations ${ }^{24}$. In this study, color change $\left(\Delta \mathrm{E}_{\mathrm{ab}}\right)$ was evaluated using a spectrophotometer, which is an instrument that produces reliable values with excellent repeatability. Based on the results of the present study, the null hypothesis was rejected, since the placement techniques affected the color and surface roughness $\left(R_{a}\right)$ of both resin composites.

Significant color change was observed among the resin composites regardless of the placement techniques used, with higher $\Delta \mathrm{E}_{\mathrm{ab}}$ for the Filtek ${ }^{\mathrm{TM}} \mathrm{Z} 350$ XT resin. When visual perceptibility and acceptability thresholds were considered, although Filtek ${ }^{\mathrm{TM}}$ Z250 XT presented better color stability 25 , both resin composites reached $\Delta \mathrm{E}_{\mathrm{ab}}$ values above the acceptable range, and would probably lead to replacement of the restoration for esthetic reasons. The increased staining susceptibility may be attributed to the composition of the resin composite organic matrix ${ }^{1,8,14}$. Filtek ${ }^{\mathrm{TM}} \mathrm{Z} 350 \mathrm{XT}$ contains hydrophilic monomers, such as TEGDMA, which tends to present higher stain susceptibility by water sorption and transport of pigments through the resin matrix. In contrast, the monomers Bis-GMA, UDMA, and Bis-EMA present in Filtek ${ }^{\mathrm{TM}}$ Z250 XT provide it with higher hydrophobicity and, consequently, lower water uptake and greater color stability ${ }^{8}$.

As the organic matrix, filler content plays an important role in color stability and $\mathrm{R}_{\mathrm{a}}$ of resin composites. The presence of large inorganic particles and interstitial spaces increases roughness and stain susceptibility by facilitating the deposition of food pigments on the restoration surface. The combination of nanofillers in nanoclusters - as founded in Filtek ${ }^{\mathrm{TM}} \mathrm{Z350}$ XT - reduces the interstitial space between filler particles by increasing the percentage of fillers in the material and improving physical properties such as surface smoothness ${ }^{8}$. However, the present study revealed that Filtek ${ }^{\mathrm{TM}} \mathrm{Z} 350 \mathrm{XT}$ presented similar $\mathrm{R}_{\mathrm{a}}$ and lower color stability for most placement techniques compared with Filtek ${ }^{\mathrm{TM}} \mathrm{Z} 250$ XT.

The present study revealed that surface sealant application resulted in higher $\Delta \mathrm{E}_{\mathrm{ab}}$ in both resin composites, even though the surface sealant was applied after polishing and was polymerized with glycerin gel to prevent the formation of oxygen-inhibition layer ${ }^{21}$. The higher $\Delta \mathrm{E}_{\mathrm{ab}}$ may be explained by the absence of inorganic fillers in the composition of the surface sealant used in this study, which may have favored the staining of the surface layer of the resin composite.

The critical value for mean $R_{a}$ is $0.2 \mu \mathrm{m}$, i.e., $R_{a}$ with higher threshold values tend to lead to bacterial accumulation and, consequently, to gingival inflammation or secondary caries ${ }^{7}$. This study found that Mylar strip was the only placement technique that provided $\mathrm{R}_{\mathrm{a}}$ within the acceptable threshold $(<0.2 \mu \mathrm{m})$ in both resin composites. The greater smoothness provided by the Mylar strip may be related to the presence of a larger amount of organic matrix on the restoration surface. These results are in agreement with those reported by Tuncer et al. ${ }^{20}$, who obtained smoother surfaces with Mylar strips compared with those finished using aluminum discs.

Possible adverse effects caused by the placement techniques can be minimized by appropriate polishing techniques ${ }^{13}$. In the present study, the specimens were polished after different 
placement techniques - except for the Mylar strip - with a multi-step polishing system that provides excellent smoothness ${ }^{20}$. Higher $\mathrm{R}_{\mathrm{a}}$ values were achieved with the Spatula and Surface Sealant techniques for the Filtek ${ }^{\mathrm{TM}} \mathrm{Z} 350$ XT resin composite. Despite the fact that the same polishing system with standardized steps was applied in all test groups, it was not able to compensate the different types of voids left by the placement techniques.

Modeling liquids are used to facilitate the handling, accommodation and contouring of resin composites ${ }^{12-14,20}$. Color change of resin composites may be influenced by the composition of the modeling liquid. Hydrophobic adhesives, when used as modeling liquids, tend to present greater color stability, whereas adhesives with hydrophilic properties tend to present increased color change ${ }^{12,14}$. In the present study, Adper Single Bond was applied on the surface layer of the resin composites and, despite its hydrophilic nature, color and $\mathrm{R}_{\mathrm{a}}$ were not negatively affected. These findings are in agreement with studies that evaluated the use of adhesives as modeling liquids ${ }^{12,14}$.

Professionals should be aware of the effects of placement techniques and resin composite type on color and $\mathrm{R}_{\mathrm{a}}$ of resin composites, because esthetic factors are one of the main reasons for resin composite restoration replacement on anterior teeth ${ }^{10}$. Current knowledge on placement techniques is limited and more studies are needed to elucidate the effects of the insertion protocols and placement techniques on the physical properties, esthetic outcome, and longevity of dental restorations.

\section{CONCLUSION}

Color stability and surface roughness $\left(\mathrm{R}_{\mathrm{a}}\right)$ were influenced by the placement techniques. The nanohybrid resin composite (Filtek ${ }^{\mathrm{TM}} \mathrm{Z} 250 \mathrm{XT}$ ) presented greater color stability compared with that of the nanofilled resin composite (Filtek ${ }^{\mathrm{TM}} \mathrm{Z} 350 \mathrm{XT}$ ). Application of surface sealant resulted on greater color change $\left(\Delta \mathrm{E}_{\mathrm{ab}}\right)$ in both resin composites. The Mylar strip technique provided lower $\mathrm{R}_{\mathrm{a}}$ in both resin composites.

\section{REFERENCES}

1. Angerame D, De Biasi M. Do nanofilled/nanohybrid composites allow for better clinical performance of direct restorations than traditional microhybrid composites? A systematic review. Oper Dent. 2018 Jul-Aug;43(4):E191-209. http://dx.doi.org/10.2341/17-212-L. PMid:29570022.

2. Baldissera RA, Corrêa MB, Schuch HS, Collares K, Nascimento GG, Jardim PS, et al. Are there universal restorative composites for anterior and posterior teeth? J Dent. 2013 Nov;41(11):1027-35. http://dx.doi.org/10.1016/j.jdent.2013.08.016. PMid:24001506.

3. Mara da Silva T, Barbosa Dantas DC, Franco TT, Franco LT, Rocha Lima Huhtala MF. Surface degradation of composite resins under staining and brushing challenges. J Dent Sci. 2019 Mar;14(1):87-92. http://dx.doi.org/10.1016/j.jds.2018.11.005. PMid:30988884.

4. Nocca G, Callà C, Martorana GE, Cicillini L, Rengo S, Lupi A, et al. Effects of dental methacrylates on oxygen consumption and redox status of human pulp cells. BioMed Res Int. 2014;2014:956579. http://dx.doi.org/10.1155/2014/956579. PMid:24693541.

5. Pagano S, Coniglio M, Valenti C, Negri P, Lombardo G, Costanzi E, et al. Biological effects of resin monomers on oral cell populations : descriptive analysis of literature. Eur J Paediatr Dent. 2019 Sep;20(3):224-32. http://dx.doi.org/10.23804/ejpd.2019.20.03.11. PMid:31489823.

6. Motevasselian F, Zibafar E, Yassini E, Mirzaei M, Pourmirhoseni N. Adherence of Streptococcus mutans to microhybrid and nanohybrid resin composites and dental amalgam: an in vitro study. J Dent (Tehran). 2017 Nov;14(6):337-43. PMid:29942328. 
7. Choi M-S, Lee Y-K, Lim B-S, Rhee S-H, Yang H-C. Changes in surface characteristics of dental resin composites after polishing. J Mater Sci Mater Med. 2005 Apr;16(4):347-53. http://dx.doi.org/10.1007/s10856-005-0634-9. PMid:15803280.

8. Alzraikat H, Burrow MF, Maghaireh GA, Taha NA. Nanofilled resin composite properties and clinical performance: a review. Oper Dent. 2018 Jul-Aug;43(4):E173-90. http://dx.doi.org/10.2341/17-208-T. PMid:29570020.

9. Kumar N, Sangi L. Water sorption, solubility, and resultant change in strength among three resin-based dental composites. J Investig Clin Dent. 2014 May;5(2):144-50. http://dx.doi.org/10.1111/jicd.12012. PMid:23188774.

10. Demarco FF, Collares K, Coelho-de-Souza FH, Correa MB, Cenci MS, Moraes RR, et al. Anterior composite restorations: a systematic review on long-term survival and reasons for failure. Dent Mater. 2015 Oct;31(10):1214-24. http://dx.doi.org/10.1016/j.dental.2015.07.005. PMid:26303655.

11. Demarco FF, Collares K, Correa MB, Cenci MS, Moraes RR, Opdam NJ. Should my composite restorations last forever? Why are they failing? Braz Oral Res. 2017 Aug;31(suppl 1):e56. http://dx.doi.org/10.1590/1807-3107bor-2017.vol31.0056. PMid:28902236.

12. Sedrez-Porto JA, Münchow EA, Cenci MS, Pereira-Cenci T. Translucency and color stability of resin composite and dental adhesives as modeling liquids - a one-year evaluation. Braz Oral Res. 2017 Jul;31(0):e54. http://dx.doi.org/10.1590/1807-3107bor-2017.vol31.0054. PMid:28678973.

13. Sedrez-Porto JA, Münchow EA, Brondani LP, Cenci MS, Pereira-Cenci T. Effects of modeling liquid/resin and polishing on the color change of resin composite. Braz Oral Res. 2016 Aug;30(1):S180683242016000100275. http://dx.doi.org/10.1590/1807-3107BOR-2016.vol30.0088. PMid:27556554.

14. Münchow EA, Sedrez-Porto JA, Piva E, Pereira-Cenci T, Cenci MS. Use of dental adhesives as modeler liquid of resin composites. Dent Mater. 2016 Apr;32(4):570-7. http://dx.doi.org/10.1016/j.dental.2016.01.002. PMid:26850844.

15. Lepri CP, Palma-Dibb RG. Influence of surface sealant on the color-stability of a composite resin immersed in different beverages. Oral Health Dent Manag. 2014 Sep;13(3):600-4. PMid:25284519.

16. Brooksbank A, Owens BM, Phebus JG, Blen BJ, Wasson W. Surface sealant effect on the color stability of a composite resin following ultraviolet light artificial aging. Oper Dent. 2019 May-Jun;44(3):322-30. http://dx.doi.org/10.2341/18-053-L. PMid:30444695.

17. Ruschel VC, Bona VS, Baratieri LN, Maia HP. Effect of surface sealants and polishing time on composite surface roughness and microhardness. Oper Dent. 2018 Jul-Aug;43(4):408-15. http://dx.doi.org/10.2341/17-048-L. PMid:29630480.

18. Pedroso LB, Barreto LFC, Miotti LL, Nicoloso GF, Durand LB. Effect of a surface sealant on the color stability of composite resins after immersion in staining solution. Gen Dent. 2016 Mar-Apr;64(2):e225. PMid:26943097.

19. CIE Central Bureal. CIE technical report: colorimetry. 3rd ed. Vienna: CIE Central Bureal; 2004.

20. Tuncer S, Demirci M, Tiryaki M, Ünlü N, Uysal Ö. The effect of a modeling resin and thermocycling on the surface hardness, roughness, and color of different resin composites. J Esthet Restor Dent. 2013 Dec;25(6):404-19. http://dx.doi.org/10.1111/jerd.12063. PMid:24172016.

21. Khalaj K, Soudi A, Tayefi-Nasrabadi M, Keshvad MA. The evaluation of surface sealants' effect on the color stability of nano-hybrid composite after polishing with one-step system (in-vitro). J Clin Exp Dent. 2018 Sep 1;10(9):e927-32. https://doi.org/10.4317/jced.54857. PMid: 30386527.

22. Prodan DA, Gasparik C, Mada DC, Miclăuş V, Băciuţ M, Dudea D. Influence of opacity on the color stability of a nanocomposite. Clin Oral Investig. 2015 May;19(4):867-75.

http://dx.doi.org/10.1007/s00784-014-1315-1. PMid:25217277. 
23. National Coffee Association Blog. NCA National Coffee Data Trends 2019 [Internet]. 2019 [cited 2019 Oct 29]. Available from: https://nationalcoffee.blog/2019/03/09/national-coffee-drinking-trends2019

24. Pecho OE, Ghinea R, Alessandretti R, Pérez MM, Della Bona A. Visual and instrumental shade matching using CIELAB and CIEDE2000 color difference formulas. Dent Mater. 2016 Jan;32(1):82-92. http://dx.doi.org/10.1016/j.dental.2015.10.015. PMid:26631341.

25. Paravina RD, Pérez MM, Ghinea R. Acceptability and perceptibility thresholds in dentistry: a comprehensive review of clinical and research applications. J Esthet Restor Dent. 2019 Mar;31(2):10312. http://dx.doi.org/10.1111/jerd.12465. PMid:30891913.

\section{CONFLICTS OF INTERESTS}

The authors declare no conflicts of interest.

\section{${ }^{*}$ CORRESPONDING AUTHOR}

Letícia Brandão Durand, Rua Tiradentes 76/304, Bairro Centro, 97050-730 Santa Maria - RS, Brasil, e-mail: leticia_durand@yahoo.com

Received: January 21, 2021

Accepted: February 4, 2021 